\title{
International Foreign Relations Law
}

\section{Executive Authority in Entering and Exiting Treaties}

\author{
Edward T. Swaine
}

The nascent field of comparative foreign relations law is generating considerable, and understandable, excitement, including for the world of treaties. ${ }^{1}$ Comparativism offers different systems the opportunity to learn from one another, and treaties offer a particularly interesting classroom. States parties are to an extent allies in a common cause, and profit mutually from a better understanding of domestic treaty-making and its constraints. Yet they are simultaneously rivals that seek to minimize the strategic opportunities afforded others - including under the agreements binding them. It is unsurprising, given these conflicting impulses, that state systems show variety in how they tackle even these common problems.

What may be more surprising is international law's apparent agnosticism. Treaties depend on foreign relations law: the latter, after all, is tasked not only with establishing domestic authority to allow states to consent to treaty obligations, but also with establishing the means by which they fulfill the resulting obligations, including through the incorporation of treaties into domestic law. Even so, international law treats structural provisions of domestic constitutions as matters of indifference. Domestic laws, the Permanent Court of International Justice once pronounced, 'are merely facts' in relation to international obligations, ${ }^{2}$ and this view remains broadly

1 See, e.g., Curtis A. Bradley (ed.), The Oxford Handbook of Comparative Foreign Relations Law (New York: Oxford University Press, 2019).

2 See Case concerning certain German interests in Polish Upper Silesia, Merits, PCIJ Series A, No. 7, 1926, p. 19 ('From the standpoint of International Law and of the Court which is its organ, municipal laws are merely facts which express the will and constitute the activities of States, in the same manner as do legal decisions or administrative measures. ... [T] here is nothing to prevent the Court's giving judgment on the question whether or not, in applying that law, Poland is acting in conformity with its obligations towards Germany under the Geneva Convention'). 
valid today. ${ }^{3}$ For reasons suggested in this chapter, domestic foreign relations law is distinguishable, at least where it facilitates international law rather than posing an obstacle to it. Nonetheless, international law seems disposed against deferring to domestic legal systems, and those systems likewise seem biased against inviting external evaluation.

The supposed agnosticism of international law toward foreign relations law seems vaguely implausible - after all, treaties and customary international law foster and monitor the human rights-conferring aspects of domestic legal orders, so it is odd that they would cede everything structural, including the means by which states assume many such obligations - and does not, in any event, mean that it leaves the latter undisturbed. As others have explored, international law creates an arena in which domestic actors assume additional authority. For example, US foreign relations law has permitted the executive branch to assume a capacity for creating and terminating international obligations that has enhanced its institutional advantages over Congress. ${ }^{4}$ Here I draw attention to a related, but materially distinct, phenomenon: how international law - specifically, treaty-law principles reflected in the Vienna Convention on the Law of Treaties (VCLT) ${ }^{5}$ - itself reinforces such tendencies in domestic institutions. ${ }^{6}$ Based on plausible, historically grounded assumptions about how states conduct foreign relations, international law has homogenized foreign relations law relating to the creation and elimination of international treaty obligations - encouraging even those states that possess other constitutional agents to regard executive power as sufficient. I examine ratification (Section I), in which this tendency is fully expressed, and then

3 James Crawford, Brownlie's Principles of Public International Law, 8th ed. (Oxford: Oxford University Press, 2012), p. 51; Robert Jennings and Arthur Watts (eds.), Oppenheim's International Law, gth ed., 2 vols. (Essex: Longman, 1992), vol. 1, p. 83; e.g., Case Concerning the Arrest Warrant of 11 April 2000 (Democratic Republic of the Congo v. Belgium), Separate Opinion of Judge Bula-Bula, I.C.J. Reports 2002, p. 100, 130-31, para. 93. See also International Law Commission, Articles on Responsibility of States for Internationally Wrongful Acts, article 3 ('The characterization of an act of a State as internationally wrongful is governed by international law. Such characterization is not affected by the characterization of the same act as lawful by internal law.').

4 Curtis A. Bradley and Jack L. Goldsmith, 'Presidential Control Over International Law' (2018) ${ }_{131}$ Harvard Law Review 1201; Jean Galbraith, 'International Law and the Domestic Separation of Powers' (2013) 99 Virginia Law Review 987.

5 Vienna Convention on the Law of Treaties, Vienna, 23 May 1969, in force 27 January 1980, 1155 UNTS 331; (1969) 8 ILM 679; UKTS (1980) 58.

6 Much the same may be said to hold for customary international law and its formation - though the capacity of a state to eliminate customary obligations is more constrained and hence less subject to executive-branch appropriation. 
withdrawal (Section II), in which it is only just emerging. ${ }^{7}$ Such analyses seek to augment a purely comparative approach to foreign relations with a fuller recognition of the influence of international law. ${ }^{8}$

\section{RATIFICATION}

Treaty law long accorded conclusive significance to treaty ratification by executives as an incident of the sovereign power of monarchs - passed along, naturally, to those with full powers to act on the sovereign's behalf. ${ }^{9}$ This was challenged by two developments. First, beginning by the midnineteenth century, a practice emerged in which states adopted constitutional provisions that required legislative approval of treaties. That tendency continues largely unabated today; the subjects encompassed by such provisions have often been expanded, along with the widening scope of treaty-making generally, and there has even been an uptick in supermajority requirements. ${ }^{10}$ Second, agreements became more varied and often more informal, resulting in many that arguably did not require approval by traditional, treaty-oriented mechanisms. ${ }^{11}$ The first development meant that ratification was transformed from a formal and infrequent act by which sovereigns confirmed, as a matter of obligation, that their representatives had been authorized to reach agreement, into a legislative referendum on the underlying merits of the agreement. But the second development meant that ratification might sometimes be dispensed with altogether, and agreements concluded based on signature alone. ${ }^{12}$

7 For brevity, I use terms like 'treaty', 'ratification' and 'withdrawal' broadly (and loosely) here, so as to include distinct acts that are similar with respect to the matters under discussion - such as, respectively, 'agreement', 'accession' and 'termination'.

8 While this chapter was in draft, an important article with a comparable approach - albeit less acutely focused on the reinforcement of executive authority, and with different prescriptive impulses - was published. See Hannah Woolaver, 'From Joining to Leaving: Domestic Law's Role in the International Validity of Treaty Withdrawal' (2019) 30 European Journal of International Law 73.

9 See Pierre-Hugues Verdier and Mila Versteeg, 'Separation of Powers, Treaty-Making, and Treaty Withdrawal: A Global Survey', in Curtis A. Bradley (ed.), The Oxford Handbook of Comparative Foreign Relations Law (Oxford: Oxford University Press, 2019), p. 138 (citing Luzius Wildhaber, Treaty-Making Power and Constitutions: An International and Comparative Study (Basel and Stuttgart: Helbing \& Lichtenhahn, 1971), p. 9).

10 See Verdier and Versteeg, 'Separation of Powers', pp. 139-41. As the authors observe, the proportion of states with such requirements dipped with the wave of new postcolonial states following World War II, but many eventually followed suit.

11 Verdier and Versteeg, 'Separation of Powers', pp. 142-47.

12 Draft Articles on the Law of Treaties with Commentaries, (1966) 2 Yearbook of the International Law Commission 187, 197, UN Doc. A/CN.4/SER.A/1966/Add.1 (discussing draft Article 11). 
The significance for the law of treaties was hotly contested, including as to whether the violation of a state's constitutional requirement of legislative approval affected whether a nonconforming treaty nonetheless bound the state under international law. Most agreed that domestic law regulated competence to consent to treaties and (often distinctly) governed competence to notify that consent to other states. But the consequences when consent had been notified by a state official competent to that role - notwithstanding the absence of valid consent under domestic law - were unsettled, and occasioned a diverse range of views that flourished from the interwar period through the drafting of the VCLT. ${ }^{33}$

At one end of the spectrum, some suggested that international law treated notification by a competent notifying official as conclusive, either as a matter of dogma or based on a state's responsibility to make good the acts of its officials. At the other extreme, some regarded constitutional law as being conclusive as to both the domestic and international effectiveness of consent. In the middle were those who regarded constitutional deficiencies as potentially bearing on international efficacy, but varying as to when. ${ }^{14}$ The Harvard Research study, after extensive canvassing of publicists, state practice and jurisprudence, decided - almost arbitrarily - to recommend codifying that '[a] State is not bound by a treaty made on its behalf by an organ or authority not competent under its law to conclude the treaty', but that a nonbound state might then be responsible for the reasonable reliance of others on its prior representations. ${ }^{15}$ Under this approach, international law deferred to foreign relations law, but ameliorated any adverse effect on other states through a liability rule.

The matter was revisited by the International Law Commission (ILC) in drafting the VCLT. Initially, the ILC's view was similar to that of Harvard Research: for a treaty to be binding on a state, it had to be adopted 'in accordance with its constitutional law and practice through an organ competent for that purpose'. ${ }^{16}$ Then it reversed course. The ILC's next proposal stressed state autonomy and self-help: states could always, if they chose, negotiate ratification terms that accommodated domestic processes, seek

13 For an early entry, see, e.g., Charles Fairman, 'Competence to Bind the State to an International Engagement' (1936) 30 American Journal of International Law 439; for a later survey, see Woolaver, 'From Joining to Leaving', 84-93.

14 For excellent surveys, see Fairman, 'Competence to Bind the State', and Harvard Research on International Law, 'Draft Convention on the Law of Treaties: Text with Comment' (1935) 29 American Journal of International Law Supplement 666, 992-1002.

15 Harvard Research, 'Draft Convention on the Law of Treaties', 992 (Article 21).

16 Draft Articles on the Law of Treaties, at p. 240 and n. 205 (quoting (1951) 2 Yearbook of the International Law Commission 73). 
collateral arrangements, caveat their signatures, qualify full powers or improve disclosures to other states during negotiations. ${ }^{17}$ If, despite these options, states behaved internationally in ways that were incompatible with their domestic constitutions, the proposal would be less forgiving. The draft precluded a state from invalidating its consent by invoking the violation of ' $a$ provision of its internal law regarding competence to conclude treaties' unless that violation was 'manifest'. ${ }^{18}$ This was later enhanced, in Article 46 of the VCLT, to define what 'manifest' meant - signifying a violation that would be 'objectively evident' to any state acting normally and in good faith and to require that the violation also concern 'a rule of its internal law of fundamental importance'. ${ }^{19}$

The ILC took commentary and practice to lean, slightly, in favor of its resolution, and noted support from governments. But its conclusion also had a normative underpinning. In its view, recent treaty-making procedures had 'done all that can be reasonably demanded ... in the way of taking account of each other's constitutional requirements'. Moreover, in most cases, states invoking the failure to abide by constitutional requirements had other motives for attempting to escape their obligations, and indulging them would threaten the security of treaty obligations. ${ }^{20}$

The VCLT thus wound up contributing to an important divide. Treaty law ceded to each state the determination of the organs and procedures by which its will to conclude treaties is formed', concerning itself 'exclusively with the external manifestations of this will on the international plane' - meaning that the international-law determination of whether a state's agent was competent to commit the state largely superseded, for international purposes, any other constitutional delicts. In principle, as the ILC explained, each government 'had the necessary means of controlling the acts of its representative and of giving effect to any constitutional requirements', and perhaps making any failings 'the clear responsibility of the Government of the State concerned' was more feasible. Any other approach, it suggested, 'would certainly be regarded as an inadmissible interference' in another state's internal affairs, particularly those that followed more dualistic approaches to the relationship between international and domestic law. ${ }^{21}$

Draft Articles on the Law of Treaties, at p. 198 (discussing draft article 11).

Draft Articles on the Law of Treaties, at p. 240.

VCLT, art. 46. The rule was reinforced by Article 27, which provided that 'A party may not invoke the provisions of its internal law as justification for its failure to perform a treaty', save as indicated by Article 46 .

20 Draft Articles on the Law of Treaties, at pp. 241-42.

${ }^{21}$ Draft Articles on the Law of Treaties, at Pp. 241-42. 
This was not the only possible international rule, even by the ILC's lights. And every approach the ILC considered, not just the one it ultimately adopted, allowed states to work around the default by developing treaty practices that respected both constitutional requirements and the conclusion of treaties. ${ }^{22}$ Unsurprisingly, though, the default it adopted was urged by governments: in practical terms, the executive representatives of governments, who were also the rule's beneficiaries. These representatives would retain primary authority over any workarounds that treaty negotiations might yield. More basically, the VCLT rule established an international-law constraint on foreign relations law. A state's representatives, rather than the state as a whole, would be entrusted (absent extraordinary circumstances) with exclusive responsibility for determining whether a state had complied with its constitutional rules, irrespective of whether those rules vested them with such responsibility or purposefully divided domestic treaty-making authority. Even in the event of manifest violations, it would ordinarily fall to those same representatives to invoke any transgression - one made through themselves or other executive-branch agents - unless the domestic legislature or some third party developed standing to do so.

There was never any illusion that this would permit the vindication of constitutional norms, even those expressed by laws regarding competence to enter into treaties. There had already been well-known instances in which Luxembourg and Argentina had acceded to the League of Nations despite violations of provisions in their constitutions requiring parliamentary approval though there was room for disagreement as to whether these violations had been ignored as merely domestic matters or whether tacit parliamentary approvals might be surmised from their funding of League participation. ${ }^{23}$ The ILC itself emphasized the exceptional nature of manifest violations, and even that other states had never acquiesced in attempts to invoke such violations. ${ }^{24}$

Subsequent assessments, and subsequent practice, only vindicate its assessment. The governments of major powers have rebuffed criticisms that they ignored the obligation to secure legislative assent, without any apparent effect

22 This impression was reinforced by the ILC's discussion as to whether the VCLT should presume that treaties were to be ratified unless stated otherwise (the rule it initially proposed) or require ratification when a treaty so provides (the rule eventually adopted). As the ILC itself explained, its choice of default was considered substantively insignificant, and it chose the path it did to accommodate government input and avoid the problem of drafting exceptions. Draft Articles on the Law of Treaties, at pp. 197-98.

23 For discussion, see Michael Bothe, 'Article 46', in Oliver Corten and Pierre Klein (eds.), The Vienna Conventions on the Law of Treaties: A Commentary, 2 vols. (Oxford: Oxford University Press, 2011), vol. II, at p. 1096.

24 Draft Articles on the Law of Treaties, at pp. 241-42. 
on their international obligations. ${ }^{25}$ Most prominently, the International Court of Justice rejected Nigeria's contention that a bilateral declaration with Cameroon was nonbinding because the Nigerian constitution at the time required approval of its Supreme Military Council; while the provision was of 'fundamental importance' under Article 46, it was not sufficiently 'manifest', including in part because heads of state could be presumed competent. ${ }^{26} \mathrm{~A}$ later judgment was to much the same effect, and made clear that - even though the Somali Parliament had rejected an agreement, making relatively prominent its potential authority under domestic law - that mattered little when the Prime Minister of Somalia failed to question its validity in later interactions on the international plane. ${ }^{27}$

It is possible that the rise in legislative authority at the national level might shape international expectations and make deviations sufficiently apparent to register as manifest, though the trend has yet to have any such effect; perhaps the nascent project on comparative foreign relations law will even assist by illuminating pertinent commonalities and differences. ${ }^{28}$ It is unlikely, in any case, that the basic rule will be reconsidered. If anything, parallel developments suggest similar biases toward the creation of international obligations and against means by which they might be subverted. The unilateral acts doctrine, per the ILC's Guiding Principles of 2006, likewise indicates that while "[a] unilateral declaration binds the State internationally only if it is made by an authority vested with the power to do so', necessarily ' $[\mathrm{b}] \mathrm{y}$ virtue of their functions, heads of State, heads of Government and ministers for foreign affairs are competent to formulate such declarations'. ${ }^{29}$

25 Bothe, 'Article 46', at pp. 1092, 1094-96 (citing German and US examples).

26 Land and Maritime Boundary between Cameroon and Nigeria (Cameroon v. Nigeria: Equatorial Guinea intervening), Judgment, I.C.J. Reports 2002, p. 303, 430-31, paras. 264-66; see, especially, p. 430 , para. 265 (explaining that 'a limitation of a Head of State's capacity in this respect is not manifest in the sense of Article 46, paragraph 2, unless at least properly publicized', and that ' $[\mathrm{t}] \mathrm{his}$ is particularly so because Heads of State belong to the group of persons who, in accordance with Article 7, paragraph 2, of the [VCLT] "[i]n virtue of their functions and without having to produce full powers" are considered as representing their State').

27 Maritime Delimitation in the Indian Ocean (Somalia v. Kenya), Preliminary Objections, Judgment, I.C.J. Reports 2017, p. 3, 24, para. 49.

28 Karen Knop, 'Foreign Relations Law: Comparison as Invention', in Curtis A. Bradley (ed.), The Oxford Handbook of Comparative Foreign Relations Law (Oxford: Oxford University Press, 2019), pp. 54-55 (noting 'the effect that a new baseline of knowledge about domestic law could conceivably have on the law of treaties', and that '[b]y collecting constitutional law and practice on treaties across a range of states, comparative foreign law would change, and potentially equalize, what is known about states' internal law').

29 International Law Commission, 'Guiding Principles Applicable to Unilateral Declarations of States Capable of Creating Legal Obligations, With Commentaries (2006)', (2006) 2 Yearbook of the International Law Commission 369, 372 (principle 4). 
The emerging unilateral acts doctrine seems to be of a piece with the full powers doctrine for treaties and, more broadly, the executive capacity assumed for traditional sources of international law, insofar as it also encourages the stability of international commitments. ${ }^{30}$ Still, this assignment of responsibility - like treaties, to a limited class of officials, without regard to what a state's foreign relations law provides - lacks the same compelling need to find an agreeable means of concluding a principal source of international law, and lacks any explicit exception for manifest violations. Interestingly, the Guiding Principles also inhibit the 'arbitrary' revocation of such commitments, with potential parallels for treaties. ${ }^{31}$ Some governments were discontent with this exercise, but it seems to have been due primarily to the difficulty of establishing general principles - and, perhaps, the risk that they would be regarded as binding their states unintentionally - and not the risk of making international law by means that were inconsistent with domestic law. ${ }^{32}$ The basic calculation is unsurprising. A sufficiently deliberate capacity would appeal to the political actors that may make use of it, executive officials, who might have less regard to the loss in authority suffered by others. If consulted, national legislatures might be more inclined to regard the emerging doctrine as creating a new rival to treaty-making by participative means.

\section{WITHDRAWAL}

International law's attitude toward the domestic law regarding withdrawal from treaties is less concrete - but as a matter of inference, at least as indifferent. The VCLT allows a state to withdraw by consent or in conformity with a treaty's terms, or if the parties so intended or treaty's nature so implies. ${ }^{33}$ Additional provisions address notice and subsequent withdrawal for cause. ${ }^{34}$

$30 \quad$ VCLT, art. 7 .

${ }^{31}$ International Law Commission, 'Guiding Principles Applicable to Unilateral Declarations of States', at 380-81 (principle 10).

32 See generally Unilateral Acts of States - Replies from Governments to the questionnaire: report of the Secretary-General, 2000, UN Doc. A/CN.4/511. Italy, at least, did indicate that legislatures might play a role, see p. 272 of the report.

33 VCLT, arts. 54, 56. In the former, any notice period is presumably dictated by the treaty; in the latter, the state gives at least twelve months' notice.

34 Where cause is invoked, a party is to notify others of its proposed withdrawal and seek their approval; if others object, disagreements are subject to a dispute resolution procedure. VCLT, arts. $65-66$. 
The ILC, in drafting the VCLT, noted that withdrawal serves as a safeguard when a state's consent to a treaty violates its constitutional principles. ${ }^{35}$ Accordingly, 'a defect in [the state's] consent to be bound' - presumably, such as would satisfy Article 46 - is one of the grounds that may be invoked and notified to other states parties. ${ }^{36}$ But nothing addresses whether there might be any 'manifest' or other constitutional violation related to the act of withdrawal itself - that is, addressing whether a state's invocation of some basis for withdrawal (or comparable act) might itself be impeached on the basis of a constitutional violation. ${ }^{37}$ The VCLT incorporates notice periods, at least as defaults, presumably for the benefit of other states parties, ${ }^{38}$ and allows the notifying state to withdraw such notice or instrument before it takes effect including, one expects, on the basis of a constitutional violation. ${ }^{39}$ But the practical significance is elusive. The timing in which a state can change its mind is a serious constraint. ${ }^{40}$ In any event, the decision appears confided to

35 Draft Articles on the Law of Treaties, at p. 242 ('Confronted with a challenge under national law of the constitutional validity of a treaty, a Government will normally seek to regularize its position under the treaty by taking appropriate action in the domestic or international sphere').

$3^{6}$ VCLT, art. 65(1).

37 See Woolaver, 'From Joining to Leaving', 93 (conceding that 'it appears that a strictly internationalist approach is applicable in the context of treaty withdrawal'); Hannah Woolaver, 'Domestic and International Limitations on Treaty Withdrawal: Lessons from South Africa's Attempted Departure from the International Criminal Court' (2017) 111 AJIL Unbound 450, 454 ('Thus, a failure by the South African executive to abide by the constitutional requirement to obtain parliamentary approval could, had it been evident to other states, have resulted in the international invalidity of its consent when joining the Rome Statute, but the very same violation would not have any international legal effect on its withdrawal from the Rome Statute').

$3^{8}$ As noted earlier, these include a period of at least twelve months' notice when a right to withdraw is implied by a treaty, see VCLT, art. 56(2), and at least three months' notice in relation to withdrawal for one of the causes indicated by Part V. See VCLT, art. 65(2). The juxtaposition of these periods is not self-evident, but that is not of direct relevance here. Theodore Christakis, 'Article 56', in Oliver Corten and Pierre Klein (eds.), The Vienna Conventions on the Law of Treaties: A Commentary, 2 vols. (Oxford: Oxford University Press, 2011), vol. II, pp. 1254-55 and note 14.

39 VCLT, art. 68.

$4^{\circ}$ In principle, as to the initial notice indicated by Article 65 , the period for revocation may exceed even the three months that article requires, but that is because the notice by itself accomplishes nothing - such that it may be waived by failing to execute withdrawal, as contemplated by Article 67, afterward. As regards execution, while the relevant instrument may also be withdrawn per Article 68, it also takes effect upon receipt, see VCLT, art. 78, so the window for revocation is likely to be vanishingly short. Antonios Tzanakopoulos, 'Article 68', in Oliver Corten and Pierre Klein (eds.), The Vienna Conventions on the Law of Treaties: A Commentary, 2 vols. (Oxford: Oxford University Press, 2011), vol. II, pp. 1566-68. 
the discretion of executive-branch officials, exactly as one might expect. ${ }^{41}$ The result, as Hannah Woolaver has observed, is that in contrast to international law powers to join treaties, the authority of the executive to withdraw the state from treaties in Article 67 of the VCLT is, prima facie, absolute in international law, unlimited by any checks that may exist in domestic law' ${ }^{42}$

This withdrawal regime now faces challenges reminiscent of those once confronted by ratification. States are slowly retreating from the practice by which the executive is entitled to withdraw unilaterally from treaties, instead adopting new provisions that require parliamentary approval. ${ }^{43}$ During the same period, multilateral and even bilateral treaty-making has seen a pronounced slowdown, ${ }^{44}$ augmented (at least in the short term) by withdrawals and similar attempts at disengagement. ${ }^{45}$ The result is that formal constitutional revision has been accompanied by high-profile instances in which executive-led attempts at withdrawal, like the United Kingdom's initial attempts to withdraw from the European Union and South Africa's (initial?) attempt to withdraw from the International Criminal Court, were slowed by judicial decisions that recognized for the first time parliamentary rights to participate in exit from certain types of treaties. ${ }^{46}$

$4^{1}$ The VCLT provides that the instruments actually executing withdrawal must be signed by the head of state, head of government, or minister of foreign affairs, or by a representative who may be asked to produce full powers. VCLT, arts. $67(2)$. The provision addressing the initial notice of cause, requires only that it be in writing, see VCLT, art. 65(1), but such matters are also traditionally assigned to the executive.

42 Woolaver, 'From Joining to Leaving', 95.

43 Verdier and Versteeg, 'Separation of Powers', p. 149 (describing a 'trend observers have largely missed: several countries already mandate parliamentary involvement in treaty withdrawal, and their numbers have been growing substantially in the last four decades'). Among the examples of states with explicit restrictions are Denmark, the Netherlands, Belgium and Chile, though in many more cases the restriction may be inferred from provisions governing both entry and exit into treaties or from constitutional decisions, see pp. 149-50. The authors do not, however, attempt to assess whether such a right of participation is respected in practice.

44 See, e.g., Joost Pauwelyn, Ramses A. Wessel and Jan Wouters, 'When Structures Become Shackles: Stagnation and Dynamics in International Lawmaking' (2014) 25 European Journal of International Law 733.

45 See, e.g., Andreas L. Paulus and Jan-Henrik Hinselman, 'International Integration and Its Counter-Limits: A German Constitutional Perspective', in Curtis A. Bradley (ed.), The Oxford Handbook of Comparative Foreign Relations Law (Oxford: Oxford University Press, 2019), pp. 419-24.

${ }^{6}$ R (Miller) v. Secretary of State for Exiting the European Union [2017] UKSC 5, [2018] AC 61; Democratic Alliance v. Minister of International Relations and Cooperation and Others 2017 (3) SA 212 (GP). Brexit was ultimately effectuated, of course, with consent from the UK - and European - parliaments. European Union (Withdrawal Agreement) Act 2020, https://services .parliament.uk/bills/2019-20/europeanunionwithdrawalagreement.html, accessed July 16, 2020; European Parliament legislative resolution of January 29, 2020 on the draft Council decision on the conclusion of the Agreement on the withdrawal of the United Kingdom of Great Britain and 
Despite the evolution of foreign relations law, there is no evident movement to develop international law. As with ratification, international law effectively regards executive determinations, in notifying a state's will, as exhausting treaty law's deference to domestic law, leaving any potential legislative role to be enforced solely through a state's own legal processes. This has clear appeal, both internationally and domestically, in instances where national requirements are as yet uncertain. But where national requirements are well defined, it remains troublingly clear that foreign relations law is not selfenforcing. For a number of actual or potential withdrawals - including those by the United States, a frequent flyer of sorts - justiciability principles are likely to limit the capacity of courts. ${ }^{47}$ Even where courts are willing and ostensibly able, any domestic principle will be difficult to apply prior to a unilateral executive notice taking effect as a matter of international law.

The readiest solution would be to infer an analogous exemption for manifest violations in the withdrawal context to match that for ratification..$^{8}$ However, that is difficult as a matter of treaty interpretation. Article $4^{6}$ is plainly limited to 'provisions of internal law regarding competence to conclude treaties'; that heads of government and comparable officials are elsewhere given authority to perform 'any other act with respect to a treaty' offers no textual basis for concluding that one of those acts, withdrawal, must also be constrained in the event of manifest violations. ${ }^{49}$ Indications in the travaux préparatoires are mixed or negative..$^{50}$ That state practice did not support any

Northern Ireland from the European Union and the European Atomic Energy Community (XT 21105/3/2018 - C9-0148/2019 - 2018/0427(NLE)), www.europarl.europa.eu/doceo/docu ment/TA-9-2020-0018_EN.html<int_u, accessed July 16, 2020. As for South Africa, withdrawal has been revived in the legislature, though without resolution to this point. International Crimes Bill, B 37-2017, www.justice.gov.za/legislation/bills/2017-b37-ICBill.pdf, accessed July 16, 2020. For discussion, see Laurence R. Helfer, "Treaty Exit and Intrabranch Conflict at the Interface of International and Domestic Law', in Curtis A. Bradley (ed.), The Oxford Handbook of Comparative Foreign Relations Law (Oxford: Oxford University Press, 2019), pp. 360-63; Hannah Woolaver, 'State Engagement with Treaties: Interactions between International and Domestic Law', in Bradley (ed.), The Oxford Handbook of Comparative Foreign Relations Law, at pp. 439-43; Woolaver, 'From Joining to Leaving', 76-80.

47 See Curtis A. Bradley and Laurence R. Helfer, 'Treaty Exit in the United States: Insights from the United Kingdom or South Africa?' (2017) 111 AJIL Unbound 428, 432 (emphasizing other dissimilarities).

$4^{8}$ See Woolaver, 'Domestic and International Limitations on Treaty Withdrawal'; Woolaver, 'State Engagement with Treaties', p. 444; Woolaver, 'From Joining to Leaving', 95-103.

49 But see Woolaver, 'Domestic and International Limitations on Treaty Withdrawal', 97 (discussing Articles 2, 7 and 67 of the VCLT).

50 Professor Woolaver points to ILC commentary indicating that the evidence of authority should be the same as between consent to be bound and withdrawal, but that does not directly implicate the Article 46 obligation. Woolaver, 'Domestic and International Limitations on 
such principle as a matter of customary international law - as Woolaver, a strong but judicious advocate for this interpretation, acknowledges ${ }^{51}$ further undermines any basis for attributing such intention to the states agreeing to the VCLT, and the lack of supportive state practice since suggests that it would be unreasonable to find any grounding in subsequent treaty practice.

To be sure, teleological or policy arguments for comparable treatment are appealing, including that the security of treaty obligations - one of the objectives of Article 46, including in limiting its exception to manifest violations only - is arguably hindered by the lack of any exception for constitutional violations regarding withdrawal, since that permits too-easy disengagement. ${ }^{2}$ Necessarily, too, the backstops are different: while withdrawal serves as a safeguard for uncorrected constitutional violations concerning ratification, re-ratification is needed to cure withdrawal in violation of domestic law, and that tends to be more cumbersome as a matter of domestic and international procedure. Finally, it may be possible to muster additional arguments for cross-applying Article 46 and its manifest violation standard. For example, one might argue that states appearing to have withdrawn might revoke a prior notification on the ground that the relevant instrument did not 'take effect' under Article 68 if it manifestly violated a constitutional requirement of legislative participation. ${ }^{53}$ No matter the precise basis, however, any such exemption would be doctrinally tenuous and narrow in its potential application. ${ }^{54}$ It remains extremely unlikely that this would change so long as the manifest violation standard serves as a catchall for redressing other, potentially unknown, constitutional violations as well.

Treaty Withdrawal', 96. As she also indicates, the question of whether Article 46 standards should also be applied to withdrawal and similar matters was expressly posed, and while those raising the issue urged that the extension be reflected in text or commentary, that was expressly deferred - with the special rapporteur, Humphrey Waldock, saying it 'would require some thought' - and nothing further was done. See p. 94 (quoting ILC, 'Summary Records of the Fifteenth Session', (1963) 1 Yearbook of the International Law Commission 164).

${ }^{11}$ Woolaver, 'Domestic and International Limitations on Treaty Withdrawal', 97.

52 Woolaver, 'Domestic and International Limitations on Treaty Withdrawal', 97-102; Helfer, 'Treaty Exit and Interbranch Conflict', p. 371.

53 What is required for a notification or subsequent instrument to 'tak [e] effect' under Article 68, however, is conventionally understood as meaning simply that it is received by the relevant depositary or states. VCLT, art. 78; see Tzanakopoulos, 'Article 68', p. 1567.

54 Thus Professor Helfer, who argues that the policy rationales for Article 46 warrant its application to states leaving treaties, suggests that - for that very reason - constitutional violations are essentially irrelevant under the international law of exit. Helfer, "Treaty Exit and Interbranch Conflict', pp. 371-72. 
What else might be engineered? If treaty law is to be progressively developed or, with great difficulty, interpreted on the basis of Article 46 or otherwise - states and treaty depositories might adopt the assumption that a withdrawal must satisfy the same separation-of-powers procedures by which the state approved consent, as an international-law embodiment of the acte contraire doctrine. That is quite vulnerable as a general principle, given the actual discrepancy in many states between domestic laws regarding legislative approvals of ratification and withdrawal. ${ }^{55}$ But the severity of any such rule may also be tempered. A state might overcome any such assumption by explaining its contrary (or still indeterminate) domestic principle. And the consequence - if a discrepancy was observed and remained unexplained, but withdrawal could still be approved in reasonable time - might not be to render the initial attempt invalid, thereby sustaining the full-fledged obligation, but instead to establish in the interim an obligation simply to abide by the treaty's object and purpose. ${ }^{56}$ Still less dramatically, governments declaring withdrawal might be required by depositories or other states simply to disclose their authority and its compatibility with constitutional requirements - which might at least have the effect of making sufficiently 'manifest' any violations of a requirement to secure legislative approval.

Other solutions involve bearing possible constitutional restraints in mind while negotiating withdrawal clauses in particular treaties. The easiest lift is to restrict any immediate effect of a notice or instrument of withdrawal - for example, by restricting when withdrawal may first be effectuated, as is typical for International Labor Organization agreements, and evidenced in the Berne Convention and the Paris Agreement ${ }^{57}$ - so as to permit legislative or judicial intervention in the case of a potentially unlawful, unilateral executive measure. More particularly, a treaty's withdrawal clause might require the disclosure of authority mentioned above, following the precedent of clauses that obligate withdrawing states to accompany their notices with explanations. ${ }^{8}$

55 As a commentator observed in another context, moreover, the notion of acte contraire is alien to international law'. Joost Pauwelyn, 'The Role of Public International Law in the WTO: How Far Can We Go?' (2001) 95 American Journal of International Law 535, 537 (discussing relationship between treaties and customary international law).

56 Cf. VCLT, art. 18.

57 See Berne Convention for the Protection of Literary and Artistic Works, Berne, September 9, 1886, as amended on September 28, 1979, in force November 19, 1984, https://wipolex.wipo.int /en/text/283698, accessed July 16, 2020, art. 35; Paris Agreement, United Nations Framework Convention on Climate Change, Report of the Conference of the Parties on the 21st Session, UN Doc. FCCC/CP/201510/Add.1, art. 28 (December 12, 2015).

$5^{8}$ See, e.g., Treaty Concerning Defense Trade Cooperation (US-UK), Washington and London, June 21 and 26, 2007, in force April 13, 2012, Senate Treaty Doc. No. 110-7 (2007), art. 20 (requiring 'a statement of the extraordinary events the notifying Party regards as having jeopardized its national interests' and warranting withdrawal); Treaty on the Non-Proliferation of Nuclear 


\section{CONCLUSION}

Foreign relations lawyers looking beyond their jurisdictions will naturally focus on any directly comparable national systems, but they should also consider the impact of international law on their discipline. First, international law not only provides opportunities for domestic actors that may be in tension with domestic principles, but also establishes rules that constrain foreign relations law. Second, while those rules of international law intend to respect ratification developments, they also guarantee that (in most circumstances) only constitutional rules assigning authority to the executive to communicate state decisions regarding ratification or withdrawal will be respected. As a result, these international rules have not adequately taken into account developments in legislative authority. Third, none of this is inevitable. In developing a comparative approach to foreign relations law, experts should not overlook the degree to which the effectiveness of domestic norms require attention to internationally established conditions.

Weapons, London, Washington and Moscow, July 1, 1968, in force March 5, 1970, 729 UNTS 161, art. X(1) (requiring 'a statement of the extraordinary events it regards as having jeopardized its supreme interests'). 